\title{
Innovation and Regional Absorptive Capacity: the Labour Market Dimension
}

\author{
Stephen Roper and James H Love \\ Aston Business School \\ Aston University \\ Birmingham B4 7ET \\ s.roper@aston.ac.uk \\ j.h.love@aston.ac.uk \\ $1^{\text {st }}$ Draft - July 2004
}

\begin{abstract}
This paper tests how the labour market characteristics of European regions shape regional absorptive capacity (RACAP), and regions' ability to assimilate knowledge from public and externally-conducted R\&D. In particular, we aim to establish whether labour market aspects of RACAP are more important for innovation in prosperous or lagging regions of the EU. Using European Innovation Scoreboard data, we estimate a RACAP-augmented regional innovation production function for $105 \mathrm{EU}$ regions.

Results indicate that there clearly are absorptive capacity effects on innovation arising from labour market influences at the regional level, and that the different organisational and individual RACAP effects are heavily contingent on regional characteristics. One of the key specific findings is that there is evidence of overinvestment in tertiary education among prosperous EU regions, while lessfavoured regions are more likely to improve their absorptive capacity by investing in lifelong learning rather than in tertiary education.
\end{abstract}

Acknowledgements: We are grateful for useful comments from participants in the $34^{\text {th }}$ Regional Studies Association International British and Irish Section Congress, Cork, August 2004.

Keywords: Innovation, Regional Absorptive capacity, Labour Market, Education.

JEL classification: $\mathrm{O} 18, \mathrm{O} 31, \mathrm{R} 12$ 


\section{Innovation and Regional Absorptive Capacity: the Labour Market Dimension}

\section{Introduction}

Since the seminal work of Cohen and Levinthal $(1989,1990)$ the notion of absorptive capacity has been widely used in the strategic management literature to capture 'the ability of an enterprise to value, assimilate and apply new knowledge'. Other recent studies have emphasised the multi-dimensional nature of absorptive capacity (ACAP), and its potential value in integrating literatures on organisational learning and resource and capability-based perspectives (Zahra and George, 2002). The concept of ACAP has been found to have particular value in studies of the relationship between knowledge acquisition and different dimensions of organisational performance ${ }^{1}$.

A natural extension of enterprise-level ACAP is to consider absorptive capacity at national or regional level, a theme most strongly associated with the literature on international technology transfer (e.g. Keller, 1996) ${ }^{2}$. As Narula (2004) emphasises, however, national or regional ACAP (RACAP) is influenced by more than the ACAP of individual enterprises, reflecting also the capability of other knowledge creating or mediating organisations in the region, and the extent of association between organisations (e.g. Morgan, 1997; Grabher and Stark, 1997; Cooke and Morgan, $1998)^{3}$. This view of RACAP draws strongly on the literature on national and regional innovation systems (e.g. Braczyk et al., 1998) and learning regions (Lundvall and Johnson, 1994) and suggests that, even given common access to technology, regional differences in labour market and industrial organisation, institutional structures, regulatory frameworks and social conventions, may lead to very different outcomes (e.g. Nelson, 1993; Braczyk et al., 1998) ${ }^{4}$.

\footnotetext{
${ }^{1}$ Zahra and George (2002) provide a comprehensive review of organisational applications of the concept of ACAP to innovation (e.g. Cohen and Levinthal, 1990; Veugelers, 1997), best practice (Szulanski, 1996), research productivity (Cockburn and Henderson, 1998), and IT adoption (Boynton, Zmud and Jacobs (1994).

${ }^{2}$ Narula (2004), p. 6, for example, quotes the definition of national absorptive capacity used by Dahlman and Nelson (1995) - 'the ability to learn and implement the technologies and associated practices of already developed countries'.

${ }^{3}$ In this sense our position reflects that of van den Bosch et al. (2002), pp. 5-8 who argue that ACAP can be envisaged at various levels of analysis: the individual, the organisational and the interorganisational. Our aim here, however, is to suggest that it is useful to integrate these perspectives rather than seeing them as alternative levels of analysis.

${ }^{4}$ For example, with respect to Germany and the UK it has been argued that different patterns of business evolution in the two countries have played an important role in
} 
We focus here on testing how the labour market characteristics of European regions shape RACAP, and regions' ability to assimilate knowledge from public and externally-conducted R\&D. A key objective is to distinguish empirically between two alternative views of the relationship between ACAP and regions' level of development. In particular, we aim to establish whether labour market aspects of RACAP are more important for innovation in prosperous or lagging regions. It may be, for example, that because of structural disadvantages associated with sectoral-mix, or a predominance of small firms, less favoured regions (LFRs) find it more difficult to appropriate spillovers from R\&D due to their limited RACAP (e.g. RodríguezPose; Roper et al., 2003) ${ }^{5}$. Or, because they are further behind the international technology frontier, it may actually be easier for LFRs to absorb new technologies than more prosperous regions whose level of technological development is already nearer to the technological frontier (e.g. Narula, 2004).

The remainder of the paper is organised as follows. Section 2 outlines our conceptual approach to RACAP emphasising its multi-level and multi-dimensional character ${ }^{6}$.

shaping the distribution of knowledge control. Chandler (1990), for example, has argued that the different characteristics of capital markets in the UK and Germany have led to different processes of conglomeratisation (see also Whittington, Mayer and Curto, 1999). The UK, it is argued, because of its relatively large capital markets, followed the US lead with larger companies involved in a process of conglomeratisation and 'over diversification' through to the 1970s, before the disinvestments and buyouts of the 1980s began to correct the trend (Chandler, 1990). Germany, and other countries in Continental Europe, however, were more easily able to avoid, and correct, the excesses of diversification: ' ... because European firms continued to rely on long-established relationships with banks and other financial institutions, they were able to pull back when such expansion did not prove profitable, and they appear to have done so in a more orderly fashion than their American counterparts' (Chandler, 1990, p.26).

${ }^{5}$ Fernandez et al. (1996) on government supported R\&D in Spain, have also suggested that the dominance of the Spanish economy by small and medium-sized firms, limits its capacity to appropriate locally the full benefits of publicly supported basic research activity. Fernandez et al. (1996) go on to suggest that for less developed regions, or those with an intermediate technological and industrial base, the locally captured social returns might be greater from investing in strategic or applied rather than basic research.

${ }^{6}$ We omit from our discussion, however, one element of absorptive capacity emphasized by Narula (2004) pp. 7-8, i.e. the ability of a national or regional economy to actively 'select and search the most appropriate technology'. In other words our use of the term absorptive capacity accords more strongly with the earlier introductory discussion in Narula (2004), i.e. 'absorptive capacity per se has little or no 
Section 3 describes the data used to explore the labour market dimensions of RACAP, and section 4 outlines our main empirical results. Section 5 concludes with some discussion of the results and the implications for future research.

\section{Regional Absorptive Capacity and the Labour Market}

Increments to knowledge can influence the level of innovation in a region through three main mechanisms: by stimulating innovation in the knowledge generating organisation itself; by generating positive rent (or pecuniary) externalities which are the result of market transactions; and, by generating pure knowledge spillovers which are independent of any market mechanism (Griliches, 1979, 1992) ${ }^{78}$. RACAP is primarily concerned with the latter two of these, i.e. the ability of a region to evaluate knowledge, to assimilate that knowledge through either rent or pure knowledge spillovers, and then apply that knowledge commercially. The complexity of this process of knowledge acquisition, assimilation and commercialisation emphasises both the multi-dimensional and multi-level nature of RACAP (e.g. van den Bosch et al., 2003), and its dependence on: (a) individual capabilities, (b) the capabilities of individual enterprises; and, (c) organisations and wider systemic capabilities.

The importance of individual capabilities in RACAP is illustrated by a number of studies which have highlighted the innovation enhancing role of individual $R \& D$ personnel, and their role as 'carriers of knowledge'. Jones and Craven (2001), for example, highlight the case of the UK Teaching Company Scheme in which a

influence on productivity, economic growth or employment. That is it is an inert concept - much like an enzyme - that only has significance as a catalyst, helping to metabolize technology flows' (p. 2).

${ }^{7}$ Another clear influence is the type of R\&D being undertaken (see Roper et al., 2004 for discussion). For example, recent evidence from Guellec and van Pottelsberghe de la Potterie (2001), who analysed $\mathrm{R} \& \mathrm{D}$ and productivity growth in 16 OECD countries, suggests that a 1 per cent increase in business $R \& D$ generates a smaller $(0.13$ per cent $)$ productivity increase than either a similar increase in foreign $\mathrm{R} \& \mathrm{D}(0.44$ per cent) or public R\&D (0.17 per cent).

${ }^{8}$ Beugelsdijck and Cornet, (2001, p. 3) summarise the distinction between rent and pure knowledge spillovers as follows:

'Rent spillovers arise when quality improvements by a supplier are not fully translated into higher prices for the buyer(s). Productivity gains are then recorded in a different firm or industry than the one that generated the productivity gains in the first place. Rent spillovers occur in input-output relations. Pure knowledge spillovers refer to the impact of the discovered ideas or compounds on the productivity of the research endeavours of others. Pure knowledge spillovers are benefits of innovative activities of one firm that accrue to another without following market transactions'. (Beugelsdijck and Cornet, 2001, p. 3). 
graduate placement from a university is based with a company to undertake a specific project. In the case they review, a graduate placed with a manufacturing company instituted ten new innovation routines of which seven were related to new information gathering or absorption ${ }^{9}$. Other evidence of the importance of individual capabilities in shaping RACAP comes from Zucker et al. (1998a, b) who examined the role of 'star' scientists in the development of the biotechnology industry in California. They concluded that the positive impact of research universities on nearby firms arises mainly from identifiable market exchanges between individual university star scientists and firms. Again the scientists were acting as conduits for the flow of knowledge between the universities and the companies with whom they were affiliated. Broader evidence of the positive impact of individual capabilities on firms' ability to commercialise knowledge through innovation is also persuasive (e.g. Freel, 2003). Recent studies, however, have also emphasised the importance of HRM practices (e.g. Michie and Sheehan, 2003) and work organisation (e.g. Finegold and Wagner, 1998) in effectively utilising individual capabilities for innovation.

Organisational capabilities of relevance to RACAP may reflect the structural characteristics of firms in a region (e.g. sectoral mix, size structure, ownership) as well as the internal capabilities of individual organisations ${ }^{10}$. Larger firms, or those in more high-tech sectors, for example, are likely to have stronger technical resources than smaller firms and therefore are more likely to be able to absorb and utilise new technologies. Hewitt-Dundas et al. (2002), for example, identify significantly higher adoption rates for a range of advanced manufacturing techniques among larger and externally-owned plants in Ireland. R\&D capability has also been found to be important in shaping firms' ability to absorb new knowledge. Veugelers and Cassiman (1999), for example, in their analysis of Belgian data suggest that firms undertaking in-house $R \& D$ benefited more from external information sources than

\footnotetext{
${ }^{9}$ The new routines introduced were literature scan, customer contacts, trade shows, idea capture form, competitor price check, customer input, supplier input. The three new routines not directly related to absorptive capacity were: new product development committee, reverse engineering and prototype development (Jones and Craven, 2001, Table 2, p. 272).

${ }^{10}$ The geographical distribution of industry within a host region may also be an important factor in determining the potential benefits which the region can capture due to spatial economies of clustering and agglomeration (e.g. Dobkins, 1996). How significant such agglomeration effects are likely to be, however, remains uncertain. Evidence from the US (e.g. Audretsch and Feldman, 1996) identifies a positive relation between R\&D spillovers and the extent of agglomeration while the European evidence is more mixed (e.g. Develaar and Nijkamp, 1989, 1992; Kleinknecht and Poot, 1992; Koschatzky et al., 1998; Roper, 2001).
} 
companies which had no in-house R\&D activity. Cassiman and Veugelers (2002) also emphasise the complementarity between internal and external R\&D activity, and demonstrate that firms engaging in both activities introduce more innovative products than firms engaged in either external or internal R\&D alone.

Alongside $\mathrm{R} \& \mathrm{D}$ other aspects of firms' internal organisation have also been shown to be important for innovation, particularly boundary spanning links between R\&D departments and other functional groups within the firm (e.g. Song et al., 1997). It has been argued, however, that establishing such relationships may be more difficult in some countries than in others. Herrigel (1996), for example, argues that the high degree of specialisation of German skilled workers and their 'culture' of disciplinary pride coupled with the narrow functional orientation of managers from different disciplines, may make it more difficult for German firms to establish cross-functional teams or integrated product development teams than those in other countries (see also Finegold and Wagner, 1998). In the UK, by contrast the weakness of the industrial training system may have the somewhat ironic advantage of avoiding some of the barriers to flexible work practices evident in German firms.

The wider, systemic, capabilities of a region's innovation system may also be important in shaping RACAP (Braczyk et al., 1998; EU, 1998; Nasierowski and Arcelus, 1999), with a particular emphasis on 'untraded interdependencies' (Dosi, 1988), knowledge 'spillovers' (Audretsch \& Feldman, 1996), knowledge integration through 'open systems architecture' (Best, 2000), and formal or informal innovation networks and joint ventures (e.g. Oerlemans et al., 1998; Love and Roper, 2001; Mamuneas and Nadiri, 1996; Veugelers and Cassiman, 1999) ${ }^{11}$. Again, however, the ability of a specific region to develop such boundary spanning links will depend on the wider social context. Lane (1997), for example, argues that the social context in the UK makes inter-firm network relationships based on mutual trust more difficult to develop than in Germany. As a result: 'The establishment and maintenance of

\footnotetext{
${ }^{11}$ To quote Metcalfe, (1997, pp. 461-462) a national or regional system of innovation is 'that set of distinct institutions which jointly and individually contribute to the development and diffusion of new technologies and which provides the framework within which governments form and implement policies to influence the innovation process. As such it is a system of interconnected institutions to create, store and transfer the knowledge, skills and artefacts which define new technology. The element of nationality follows not only from the domain of technology policy but from elements of shared language and culture which bind the system together, and from the national focus of other policies laws and regulations which condition the innovative environment'.
} 
effective supplier relations entails higher transaction costs for the firms engaged at every stage of the relationship. The absence of reliable mechanisms of risk reduction makes British managers view long-term commitments with greater wariness than their German counterparts. Close relations of technical collaboration, based on mutual trust, seem to be regarded as less feasible in the British social context' (p. 214) ${ }^{12}$.

To test the importance of labour market RACAP effects we make use a regional innovation production function (e.g. Griliches, 1979). This relates an innovation output indicator for region $j, I_{j}$, to the level of technology investment in the region, $R_{j}$, the level of public technology investment in the region, $\mathrm{P}_{\mathrm{j}}$, and national levels of business $(\mathrm{R})$ and public technology investment $(\mathrm{P})$, i.e.

$$
I_{j}=\alpha+\beta_{1} R_{j}+\beta_{2} P_{j}+\beta_{3} R+\beta_{4} P+\eta_{j}
$$

Where, $\beta_{2}$, the coefficient on public technology investments in the region, will reflect the strength of local (intra-regional) spillovers, and $\beta_{3}$ and $\beta_{4}$ will reflect inter-regional spillovers from national technology investments. Labour market RACAP effects are then captured by adding interaction effects between a series of regional labour market indicators $\mathrm{L}_{\mathrm{j}}$ and the technology investment variables, i.e.

$$
I_{j}=\alpha+\beta_{1} R_{j}+\beta_{2} P_{j}+\beta_{3} R+\beta_{4} P+\beta_{5} P_{j} L_{j}+\beta_{6} R L_{j}+\beta_{7} P L_{j}+\eta_{j}
$$

Here, $\beta_{5}$ will reflect the influence of labour market factors on regions' ability to capture intra-regional spillovers, while $\beta_{6}$ and $\beta_{7}$ will indicate the influence of the labour market in regions' ability to capture inter-regional knowledge spillovers.

Three other aspects of the model specification are also worth highlighting. First, as part of the set of regional labour market indicators, $L_{j}$, we consider variables designed to reflect both the individual and organisational capabilities of each region as discussed earlier. Secondly, to test for potential differences between labour market RACAP effects in LFRs and more prosperous regions we estimate separate

\footnotetext{
${ }^{12}$ Other forms of legal and co-operative organisation clearly exist for collaborative research and Kogut (1988), for instance, argues that joint ventures are an appropriate method of engaging in collaborative research where there is a high degree of uncertainty over specifying and monitoring performance. If, as Lane (1997) suggests, inter-firm relationships are characterised by lower levels of trust than in Germany, UK firms may find legally defined forms of research collaboration more attractive than German plants both to protect property rights and reduce transaction costs.
} 
interaction effects for each group of regions, and then test for the equality of the estimated parameters for each group of regions. Third, to condition for possible income effects we also include GDP per capita variables in each equation.

\section{Data and Estimation Methods}

Data were taken from the 2003 European Innovation Scoreboard (European Commission, 2003). This covers the whole EU15 but our analysis here is limited to seven countries (Germany, France, the Netherlands, Austria, Portugal, Finland and the UK) due to missing data in other areas (EU Commission, 2003, Appendix F). With the exception of the UK where the data is for NUTS2 regions, the analysis is at a NUTS1 level with variable definitions and descriptive statistics given in Annex 1. Three regional innovation output indicators are used, all derived from the second Community Innovation Survey ${ }^{13}$. These are: innovative sales, a measure of innovation success; and the proportions of innovative manufacturing and services businesses, both measures of the extent of innovation activity. The inclusion of this range of innovation output measures allows us to test for labour market RACAP effects on different dimensions of regional innovation outputs.

In addition to the innovation measures, the EIS includes three groups of indicators which will contribute to regional innovation. First, regional technology investments by firms are measured by the level of business R\&D spending and innovation expenditure by manufacturing and services businesses. Both will have direct effects on the level of regional innovation, with the potential for intra-regional spillovers between the manufacturing and service sectors. Second, the level of public R\&D

\footnotetext{
${ }^{13}$ The Second Community Innovation Survey (CIS 2) was undertaken in 1997 in all EU Member countries and Norway. Only enterprises with 20 or more employees were included in the sample. In each country a stratified sample frame was used reflecting enterprise size and industry classification. The sampling frames varied across countries and therefore 'the statistical significance of population values calculated on the basis of the realised sample varies... beyond national variations in response rates across strata and nationality' (Sandven, Pedersen and Smith, 1998
} p.46). See also Arundel et al. (1998). 
spending in the region - including that both by government and higher education will have the potential to generate intra-regional spillovers depending on RACAP. Third, for each region, national levels of public and business R\&D investment create the potential for inter-regional spillovers, again dependent on RACAP. To reflect the capacity of regions' labour markets to contribute to RACAP we use four separate indicators: the proportion of the working population with tertiary education and the proportion participating in life-long learning activities are used to reflect the contribution of individual capabilities to RACAP; the proportions of employment in high-tech manufacturing and services are used to reflect the contribution of organisational capabilities.

Our estimation approach is determined primarily by the nature of the dependent variables. In particular, each of the variables in the published EIS dataset is expressed in scaled form to disguise actual values, i.e. if $I_{j}$ is an indicator for region $j$, then the published data $\mathrm{X}_{\mathrm{j}}$ is: $X_{j}=\frac{I_{j}-\min \left(I_{j}\right)}{\max \left(I_{j}\right)-\min \left(I_{j}\right)}$. This is done primarily because of the 'experimental' nature of the regional innovation data derived from the Second Community Innovation Survey and ensures $1 \geq X_{j} \geq 0$. The appropriate estimator is therefore a Tobit model with upper and lower censoring. One issue which arises in using Tobit models, however, is that there is no standard counterpart to the $\mathrm{R}^{2}$ measure of fit. Alternatives have been reviewed, however, by Veall and Zimmermann (1994) and we report two such measures which conform to both of Veall and Zimmermann's desirable criteria for pseudo- $\mathrm{R}^{2}$ measures in Tobit; the ability to mimic the numeric properties of the standard $\mathrm{R}^{2}$ statistic in OLS, and being based on the full sample of both censored and non-limit observations. If $\hat{y}_{i}$ is the predicted value then these are defined as follows (Greene, 2002, p. E21-12):

$$
R_{\text {ANOVA }}^{2}=\frac{\frac{1}{n} \sum_{i=1}^{n}\left(\hat{y}_{i}-\overline{\hat{y}}\right)^{2}}{\frac{1}{n} \sum_{i=1}^{n}\left(y_{i}-\bar{y}\right)^{2}}
$$

and 


$$
R_{D E C O M P}^{2}=\frac{\frac{1}{n} \sum_{i=1}^{n}\left(\hat{y}_{i}-\bar{y}\right)^{2}}{\frac{1}{n} \sum_{i=1}^{n}\left(\hat{y}_{i}-\bar{y}\right)^{2}+\frac{1}{n} \sum_{i=1}^{n}\left(y_{i}-\hat{y}_{i}\right)^{2}}
$$

The first measure is the variance of the estimated conditional mean divided by the variance of the observed variable. The second measure is the ratio of the variance of the conditional mean around the overall mean of the data to the same measure, plus the residual variance, in the denominator.

\section{Empirical Results}

Table 1 shows the results for the baseline estimates of a regional innovation production function (equation 1) for $105 \mathrm{EU}$ regions, including conditioning variables to reflect differences in GDP per capita. As expected, regional innovation expenditure in both manufacturing and services has a strong positive effect on all three innovation output indicators. Particularly notable are the significant coefficients on manufacturing innovation expenditure on service innovation output and vice versa, suggesting strong complementarity between service and manufacturing sector innovation (see also Muller and Zenker, 2001). However, the third measure of regional technology investment by firms - business R\&D - has a significant and positive effect only on the success of manufacturing innovation, i.e. innovative sales. Evidence of intra-regional spillovers from public technology investments is weak, and marginally significant only in the case of service sector innovation. Inter-regional spillovers from national business R\&D are positive in terms of each dimension of innovation activity and significant in the case of manufacturing, while national public R\&D investment has no discernable spillover effect in manufacturing, and a marginally significant negative effect in services. Therefore at first sight there appear to be two key drivers of innovation at the EU regional level; direct investments by firms in innovation (but not necessarily in $R \& D$ ); and inter-regional spillovers from business R\&D activity elsewhere. There is almost no positive innovation benefit from either intra or inter-regional spillovers from public R\&D investments.

Tables 2, 3 and 4 report estimates of equation (2), the regional innovation production function augmented with the labour market RACAP terms, differentiating between LFRs and more prosperous regions. More specifically, Table 2 deals with the 
potential for labour market factors to help regions assimilate outside knowledge through intra-regional spillovers from local public R\&D investments, while Tables 3 and 4 focus on absorptive capacity issues relating to inter-regional spillovers from public and business $R \& D$ respectively. In the discussion that follows, Tables 2, 3 and 4 are considered together.

As indicated in the previous section, two categories of labour market RACAP effects are considered; individual (relating the educational levels in the region), and organisational (relating to employment in high-tech manufacturing and services). Tables 2, 3 and 4 reveal little consistency of effects with respect to the levels of tertiary education and extent of lifelong learning; as indicated below, this contrasts sharply with the consistently positive effect on RACAP of regions' organisational capabilities.

Our results indicate that for high income regions increased tertiary education systematically reduces RACAP for both intra and inter-regional spillovers, while for LFRs increased levels of tertiary education have a largely insignificant effect on RACAP. This is consistent with the findings of Dolton and Vignoles (2000) on the returns to education which suggest a significant degree of graduate over-education in the UK, at least. By contrast, lifelong learning has a consistently positive effect on RACAP in both LFRs and more prosperous regions, although the nature of this effect differs between these groups of regions. In LFRs the positive effect of lifelong learning occurs in regions' intra-regional RACAP, allowing local services to benefit from spillovers from the region's public R\&D spending (Table 2). In more prosperous regions, however, the positive RACAP effect of lifelong learning primarily benefits manufacturing firms which are more able to take advantage of inter-regional spillovers from both public and private R\&D investments elsewhere (Tables 3 and 4). This latter point may be a reflection of the different market orientations in the two sets of areas, with services in LFRs being primarily locally based and dependent on regional demand, contrasting with the broader inter-regional and international market orientation of manufacturing in more prosperous regions. 
Organisational RACAP effects, represented by employment in high-tech manufacturing and services, are overwhelmingly positive, most notably in the case of more prosperous regions where these effects are uniformly positive. Organisational effects are also consistently positive for manufacturing innovation in LFRs, but tend to be negative for service innovation in LFRs, significantly so on two occasions (viz.Tables 2 and 4).

The observed differences between labour market effects in LFRs and more prosperous regions are consistent with the differences in RACAP at different stages of development suggested by Narula (2004). In particular, in LFRs we observe positive intra-regional rather than inter-regional individual capability RACAP effects together with negative organisational RACAP effects in the service sector. This is consistent with a situation in which services in LFRs are more locally oriented and concentrated in lower technology sectors than that is the case in more prosperous regions. This may also in part explain why lifelong learning rather than tertiary education has a significantly positive effect for services innovation in LFRs; the key RACAP issue for locally-driven services is medium-level skills in low/medium technology sectors, which are more likely to be provided by continuing education rather than by investment in tertiary education.

\section{Conclusions}

There are two main empirical conclusions from our analysis. The first is that there clearly are RACAP effects on innovation arising from labour market influences at the regional level. This is most evident from the contrasts between Table 1, where public $R \& D$ expenditure at both the regional and national levels appear to have no effect on innovation output, and Tables 2 and 3, where there is highly significant interaction between public R\&D and individual and organisational absorptive capacity measures.

The second key conclusion is that the different organisational and individual RACAP effects are heavily contingent on regional characteristics. For example, in prosperous regions there are overwhelmingly positive organisational effects arising from the interaction between employment in high-tech manufacturing and services and public and business R\&D, and also positive lifelong learning effects for manufacturing 
innovation. The pattern for LFRs is rather different, with positive organisational effects evident only for manufacturing, but a strong positive effect from lifelong learning in services. Crucially, neither prosperous regions nor LFRs benefit from expanding tertiary education: the RACAP effect of increased levels of tertiary education is insignificant in LFRs and significantly negative in more prosperous regions. This implies that there is no benefit from tertiary education developments in either rich or poor regions, and that in more prosperous regions there is a declining marginal benefit to such developments, suggesting systematic overinvestment in higher education in these regions. Put another way, this suggest that in terms of RACAP returns to education are likely to be higher in less developed regions. This is consistent with broader international evidence on the returns to education which stress that returns tend to be inversely related to initial schooling levels and per capita incomes (e.g. Psacharopoulos, 1994).

Our results have both methodological implications and implications for regional development strategies. From a methodological standpoint, our results suggest that estimating regional innovation production functions such as equation (1) without allowing for the contingent relationship between knowledge availability and local labour market characteristics will underestimate the importance and extent of spillovers, and obscure the fact that labour market RACAP effects differ between different types of regions.

The implications for regional development strategy are fourfold. First, our results on the factors which shape regional innovation capability directly emphasise the positive and mutually reinforcing links between manufacturing and service sector innovation. As Muller and Zenker (2001) suggest, this highlights the importance of a 'balanced' development strategy, reflecting the mutual inter-dependency of different sectors of the regional economy. Second, our RACAP results that labour market policy can have an important role in shaping RACAP and is therefore an important accompaniment to broader regional innovation or development strategies. Third, in terms of RACAP, investment in tertiary education appears to be a misplaced priority in both prosperous regions and LFRs, but for different reasons in different areas. For more prosperous regions the evidence suggests that, with respect to its effect on regional absorptive 
capacity $^{14}$, there are already declining marginal returns to innovation output from increased tertiary education investment, while for LFRs the evidence suggests that there is more value in investing in lifelong learning than in tertiary education. Fourth, the organisational aspects of the labour market are also important, but policy again needs to be consistent with the developmental position of a region. For more prosperous regions policy initiatives designed to expand the proportion of high-tech employment in manufacturing and services has positive RACAP effects primarily through the increased capacity to capture inter-regional spillovers. It is markedly less clear that the same approach is applicable to LFRs. Here the evidence suggests that any expansion of high-tech employment in services actually reduces RACAP, and instead a more appropriate strategy might be oriented towards strengthening intraregional ACAP through, for example, investments in lifelong learning and in strengthening the medium/low technology service sector.

\footnotetext{
${ }^{14}$ The present study does not consider the direct effect of educational investment on innovation outputs.
} 
Table 1: Tobit Models of Innovation Output Indicators

\begin{tabular}{|c|c|c|c|c|c|c|}
\hline & \multicolumn{2}{|c|}{$\begin{array}{c}\text { Innovative } \\
\text { Sales }\end{array}$} & \multicolumn{2}{|c|}{$\begin{array}{l}\text { Percentage of } \\
\text { Innovating Firms } \\
\text { Manufacturing }\end{array}$} & \multicolumn{2}{|c|}{$\begin{array}{c}\text { Percentage of } \\
\text { Innovating Firms } \\
\text { Services }\end{array}$} \\
\hline & Coeff. & t-ratio & Coeff. & t-ratio & Coeff. & t-ratio \\
\hline Constant & -0.005 & -0.049 & 0.344 & 3.880 & 0.282 & 2.982 \\
\hline Business R\&D & 0.057 & 0.432 & -0.343 & -2.769 & -0.199 & -1.503 \\
\hline Innovation Expenditure - Manufacturing & 0.309 & 2.821 & 0.300 & 2.908 & 0.224 & 2.017 \\
\hline Innovation Expenditure - Services & 0.140 & 1.588 & 0.121 & 1.480 & 0.428 & 4.871 \\
\hline Public R\&D & 0.149 & 1.351 & 0.135 & 1.303 & 0.204 & 1.848 \\
\hline National Public R\&D & 0.020 & 0.051 & 0.023 & 0.062 & -0.653 & -1.679 \\
\hline National Business R\&D & 1.178 & 2.410 & 0.511 & 1.113 & 0.596 & 1.213 \\
\hline GDP Per Capita - Low Income & -0.054 & -1.325 & -0.043 & -1.109 & -0.037 & -0.892 \\
\hline GDP Per Capita - Very high Income & -0.018 & -0.308 & 0.107 & 1.949 & 0.066 & 1.131 \\
\hline Tertiary Education & -0.146 & -0.845 & -0.039 & -0.238 & -0.113 & -0.645 \\
\hline Lifelong Learning & -0.130 & -1.534 & 0.079 & 0.994 & 0.089 & 1.040 \\
\hline Employment M/H-T Manuf. & 0.313 & 2.380 & 0.349 & 2.823 & 0.073 & 0.553 \\
\hline Employment H-T Services & 0.049 & 0.302 & -0.108 & -0.708 & 0.008 & 0.049 \\
\hline $\mathrm{n}$ & 105 & & 105 & & 105 & \\
\hline Log-L & 38.58 & & 47.21 & & 39.38 & \\
\hline $\mathrm{R}^{2}$ Anova & 0.005 & & 0.373 & & 0.004 & \\
\hline $\mathrm{R}^{2}$ Decomp & 0.434 & & 0.482 & & 0.438 & \\
\hline
\end{tabular}

Notes and Sources: Variable definitions are given in Annex 1. $\mathrm{R}^{2}$ Anova and $\mathrm{R}^{2}$ Decomp are defined in the text. Source: EC, 2003. 
Table 2: Tobit Models with ACAP for Public R\&D

\begin{tabular}{|c|c|c|c|c|c|c|}
\hline & \multicolumn{2}{|c|}{$\begin{array}{l}\text { Innovative } \\
\text { Sales }\end{array}$} & \multicolumn{2}{|c|}{$\begin{array}{l}\text { Percentage of } \\
\text { Innovating Firms } \\
\text { Manufacturing }\end{array}$} & \multicolumn{2}{|c|}{$\begin{array}{c}\text { Percentage of } \\
\text { Innovating Firms } \\
\text { Services }\end{array}$} \\
\hline & Coeff. & t-ratio & Coeff. & t-ratio & Coeff. & t-ratio \\
\hline Constant & -0.039 & -0.291 & 0.364 & 2.965 & 0.198 & 1.544 \\
\hline Business R\&D & -0.015 & -0.111 & -0.294 & -2.270 & -0.073 & -0.543 \\
\hline Innovation Expenditure - Manufacturing & 0.282 & 2.628 & 0.243 & 2.440 & 0.154 & 1.478 \\
\hline Innovation Expenditure - Services & 0.136 & 1.529 & 0.182 & 2.247 & 0.452 & 5.333 \\
\hline Public R\&D & 0.161 & 0.402 & 0.071 & 0.193 & 0.900 & 2.345 \\
\hline National Public R\&D & 0.383 & 0.930 & 0.338 & 0.881 & -0.477 & -1.190 \\
\hline National Business R\&D & 0.731 & 1.395 & -0.043 & -0.088 & 0.199 & 0.393 \\
\hline GDP Per Capita - Lowest 4 deciles & -0.103 & -1.692 & -0.136 & -2.411 & -0.132 & -2.247 \\
\hline GDP Per Capita - Highest 2 deciles & -0.050 & -0.835 & 0.130 & 2.359 & 0.066 & 1.154 \\
\hline Tertiary Education & 0.279 & 0.896 & 0.242 & 0.844 & 0.150 & 0.501 \\
\hline Lifelong Learning & -0.243 & -1.590 & 0.010 & 0.070 & 0.015 & 0.101 \\
\hline Employment M/H-T Manuf. & 0.065 & 0.349 & 0.332 & 1.931 & 0.077 & 0.429 \\
\hline Employment H-T Services & 0.138 & 0.504 & -0.128 & -0.504 & 0.206 & 0.785 \\
\hline \multicolumn{7}{|l|}{$\begin{array}{l}\text { ACAP - Public R\&D - Less Favoured } \\
\text { Regions }\end{array}$} \\
\hline Public R\&D x Tertiary Education & -0.855 & -0.867 & 0.635 & 0.699 & -0.671 & -0.708 \\
\hline Public R\&D x Lifelong Learning & 0.600 & 1.080 & -0.037 & -0.072 & 1.394 & 2.588 \\
\hline Public R\&D x Employment M/H-T Manuf. & 1.361 & 1.031 & -0.667 & -0.546 & 0.280 & 0.219 \\
\hline Public R\&D x Employment H-T Services & -0.527 & -0.741 & -0.126 & -0.191 & -1.731 & -2.517 \\
\hline \multicolumn{7}{|l|}{$\begin{array}{l}\text { ACAP - Public R\&D - More Prosperous } \\
\text { Regions }\end{array}$} \\
\hline Public R\&D x Tertiary Education & -2.076 & -2.028 & -2.002 & -2.115 & -1.304 & -1.322 \\
\hline Public R\&D x Lifelong Learning & 0.453 & 0.772 & 0.623 & 1.145 & -0.164 & -0.289 \\
\hline Public R\&D x Employment M/H-T Manuf. & 0.986 & 1.780 & 0.200 & 0.400 & -0.505 & -0.968 \\
\hline Public R\&D x Employment H-T Services & 0.911 & 1.208 & 1.000 & 1.432 & 0.046 & 0.063 \\
\hline $\mathrm{n}$ & 105 & & 105 & & 105 & \\
\hline Log-L & 43.77 & & 53.76 & & 48.44 & \\
\hline $\mathrm{R}^{2}$ Anova & 0.05 & & 0.228 & & 0.002 & \\
\hline $\mathrm{R}^{2}$ Decomp & 0.440 & & 0.482 & & 0.437 & \\
\hline$\chi^{2}(4)$ & $4.78(\rho$ & $.310)$ & $11.41(\mathrm{p}$ & $0.022)$ & 15.58 & $.004)$ \\
\hline
\end{tabular}

Notes and Sources: Variable definitions are given in Annex 1. $\mathrm{R}^{2}$ Anova and $\mathrm{R}^{2}$ Decomp are defined in the text. The $\chi^{2}(4)$ is a Wald test for equality of the labour market RACAP terms for the LFRs and more prosperous regions. Regions are here classified as Less Favoured if they are in the lowest four deciles of the distribution of GDP per capita. Source: EC, 2003. 
Table 3: Tobit Models with ACAP for National Public R\&D Spillovers

\begin{tabular}{|c|c|c|c|c|c|c|}
\hline & \multicolumn{2}{|c|}{$\begin{array}{l}\text { Innovative } \\
\text { Sales }\end{array}$} & \multicolumn{2}{|c|}{$\begin{array}{l}\text { Percentage of } \\
\text { Innovating Firms } \\
\text { Manufacturing }\end{array}$} & \multicolumn{2}{|c|}{$\begin{array}{c}\text { Percentage of } \\
\text { Innovating Firms } \\
\text { Services }\end{array}$} \\
\hline & Coeff. & t-ratio & Coeff. & t-ratio & Coeff. & t-ratio \\
\hline Constant & -0.310 & -0.849 & 0.249 & 0.805 & 0.459 & 1.242 \\
\hline Business R\&D & 0.241 & 1.648 & -0.042 & -0.340 & -0.077 & -0.523 \\
\hline Innovation Expenditure - Manufacturing & 0.199 & 1.873 & 0.129 & 1.432 & 0.148 & 1.369 \\
\hline Innovation Expenditure - Services & 0.125 & 1.442 & 0.194 & 2.677 & 0.463 & 5.323 \\
\hline Public R\&D & 0.156 & 1.337 & 0.010 & 0.101 & 0.123 & 1.055 \\
\hline National Public R\&D & 2.209 & 1.549 & 2.346 & 1.942 & -0.369 & -0.255 \\
\hline National Business R\&D & 0.654 & 1.139 & -0.723 & -1.490 & -0.105 & -0.181 \\
\hline GDP Per Capita - Lowest 4 deciles & -0.144 & -1.208 & -0.417 & -4.131 & -0.266 & -2.207 \\
\hline GDP Per Capita - Highest 2 deciles & -0.065 & -1.067 & 0.135 & 2.624 & 0.055 & 0.899 \\
\hline Tertiary Education & -0.462 & -0.558 & -0.095 & -0.136 & 0.425 & 0.511 \\
\hline Lifelong Learning & 1.280 & 2.242 & 1.498 & 3.098 & 0.144 & 0.250 \\
\hline Employment M/H-T Manuf. & 0.074 & 0.097 & 0.069 & 0.107 & -0.062 & -0.080 \\
\hline Employment H-T Services & -0.342 & -0.547 & -0.987 & -1.874 & -0.677 & -1.079 \\
\hline \multicolumn{7}{|c|}{ ACAP - Public R\&D - Less Favoured Regions } \\
\hline Nat Public R\&D x Tertiary Education & 1.028 & 0.344 & 1.437 & 0.570 & -0.486 & -0.161 \\
\hline $\begin{array}{l}\text { Nat Public R\&D x Lifelong Learning } \\
\text { Nat Public R\&D x Employment M/H-T }\end{array}$ & -5.460 & -2.444 & -6.505 & -3.435 & 0.294 & 0.130 \\
\hline Manuf. & 0.813 & 0.246 & 1.141 & 0.407 & 0.427 & 0.128 \\
\hline \multicolumn{7}{|l|}{$\begin{array}{l}\text { ACAP - Public R\&D - More Prosperous } \\
\text { Regions }\end{array}$} \\
\hline Nat Public R\&D x Tertiary Education & 0.036 & 0.010 & -1.928 & -0.667 & -3.508 & -1.016 \\
\hline $\begin{array}{l}\text { Nat Public R\&D x Lifelong Learning } \\
\text { Nat Public R\&D x Employment M/H-T }\end{array}$ & -5.613 & -2.365 & -5.070 & -2.522 & -0.294 & -0.122 \\
\hline Manuf. & -0.096 & -0.034 & 0.005 & 0.002 & 0.217 & 0.076 \\
\hline Nat Public R\&D x Employment H-T Services & 2.710 & 1.097 & 4.298 & 2.059 & 4.000 & 1.605 \\
\hline $\mathrm{n}$ & 105 & & 105 & & 105 & \\
\hline Log-L & 46.74 & & 67.04 & & 47.796 & \\
\hline $\mathrm{R}^{2}$ Anova & 0.006 & & 0.146 & & 0.006 & \\
\hline $\mathrm{R}^{2}$ Decomp & 0.437 & & 0.481 & & 0.438 & \\
\hline$\chi^{2}(4)$ & $3.38(\rho=0$. & & $20.00(\rho=0$ & 050) & $14.95(\rho=$ & 05) \\
\hline
\end{tabular}

Notes and Sources: Variable definitions are given in Annex 1. $\mathrm{R}^{2}$ Anova and $\mathrm{R}^{2}$ Decomp are defined in the text. The $\chi^{2}(4)$ is a Wald test for equality of the labour market RACAP terms for the LFRs and more prosperous regions. Regions are here classified as Less Favoured if they are in the lowest four deciles of the distribution of GDP per capita. Source: EC, 2003. 
Table 4: Tobit Models with ACAP for National Business R\&D Spillovers

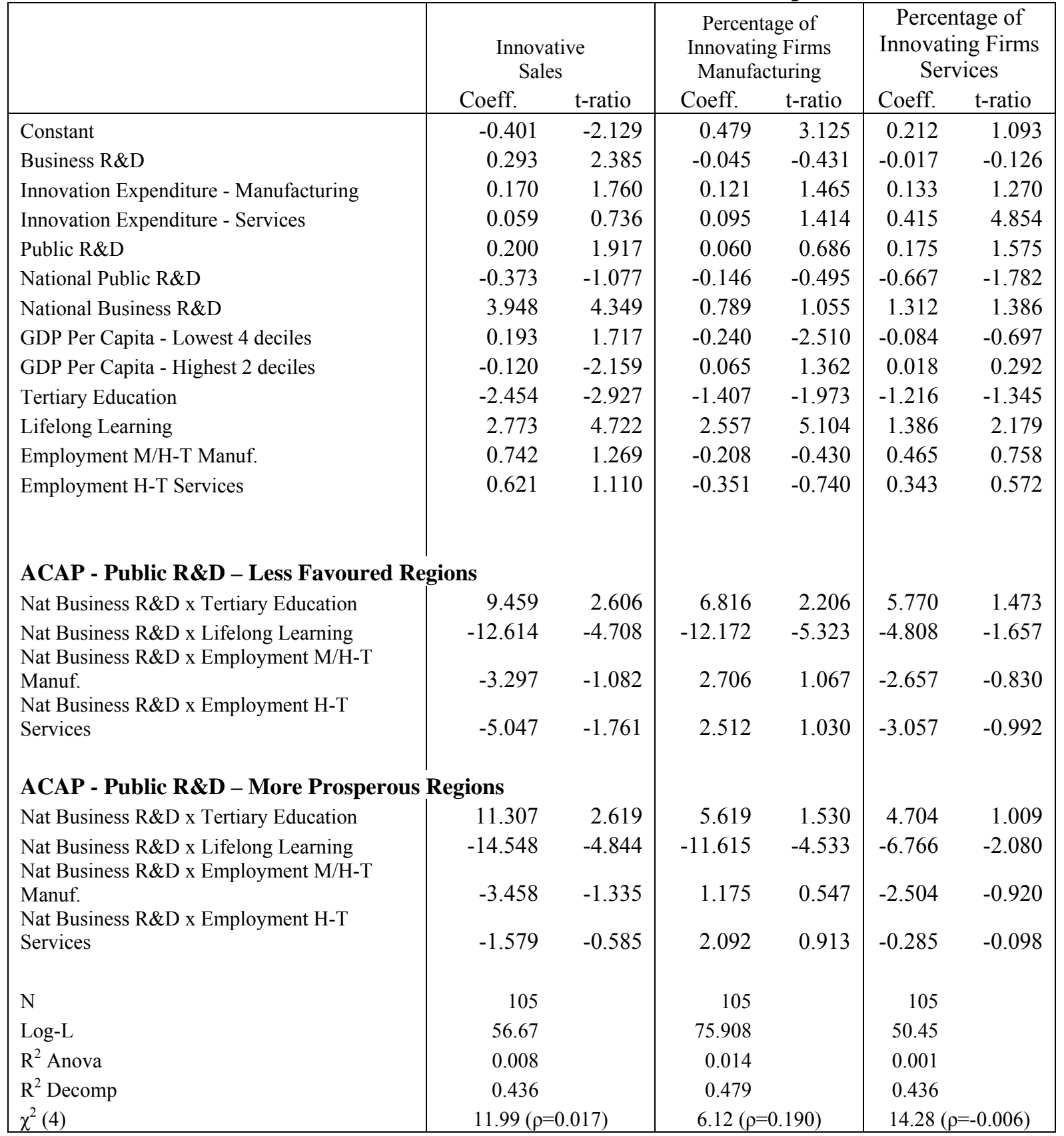

Notes and Sources: Variable definitions are given in Annex 1. $\mathrm{R}^{2}$ Anova and $\mathrm{R}^{2}$ Decomp are defined in the text. The $\chi^{2}(4)$ is a Wald test for equality of the labour market RACAP terms for the LFRs and more prosperous regions. Regions are here classified as Less Favoured if they are in the lowest four deciles of the distribution of GDP per capita. Source: EC, 2003. 
Annex: Data Definitions and Descriptive Statistics

\begin{tabular}{|c|c|c|c|}
\hline Variable Label & Definition & Mean & SD \\
\hline Innovative Sales & $\begin{array}{l}\text { Sales of new to the firm products as a } \\
\text { percentage of sales in manufacturing. } \\
\text { Source: CIS2. }\end{array}$ & 0.393 & 0.214 \\
\hline $\begin{array}{l}\text { Innovating Enterprises - } \\
\text { Manufacturing }\end{array}$ & $\begin{array}{l}\text { Proportion of innovating enterprises in } \\
\text { manufacturing. Source: CIS } 2 \text {. }\end{array}$ & 0.609 & 0.185 \\
\hline $\begin{array}{l}\text { Innovating Enterprises - } \\
\text { Services }\end{array}$ & $\begin{array}{l}\text { Proportion of innovating enterprises in } \\
\text { services. Source: CIS } 2 \text {. }\end{array}$ & 0.358 & 0.193 \\
\hline Tertiary Education & $\begin{array}{l}\text { Proportion of the } 25-64 \text { age group with a } \\
\text { post-secondary qualification. Source: } \\
\text { Labour Force Survey }\end{array}$ & 0.452 & 0.177 \\
\hline Lifelong Learning & $\begin{array}{l}\text { Proportion of the } 25-64 \text { age group } \\
\text { participating in some type of education or } \\
\text { training activity in a four week period. } \\
\text { Source: Labour Force Survey. }\end{array}$ & 0.331 & 0.269 \\
\hline $\begin{array}{l}\text { Empl. in High-Tech } \\
\text { Manufacturing }\end{array}$ & $\begin{array}{l}\text { Percentage of total workforce in high -tech } \\
\text { manufacturing (i.e. Nace } 24,29,30-35 \text { ). } \\
\text { Source: Labour Force Survey. }\end{array}$ & 0.364 & 0.196 \\
\hline $\begin{array}{l}\text { Empl. in High-Tech } \\
\text { Services }\end{array}$ & $\begin{array}{l}\text { Proportion of the total workforce in high- } \\
\text { tech services (i.e. Nace } 64,72 \text { and } 73 \text { ). } \\
\text { Source: Labour Force Survey. }\end{array}$ & 0.338 & 0.168 \\
\hline Business R\&D & $\begin{array}{l}\text { Business R\&D spending as a \% of GDP. } \\
\text { Source: Eurostat. }\end{array}$ & 0.211 & 0.179 \\
\hline $\begin{array}{l}\text { Innovation Expenditure } \\
\text { in Manufacturing }\end{array}$ & $\begin{array}{l}\text { Innovation Expenditure by manufacturing } \\
\text { firms as \% of turnover (all manufacturing } \\
\text { firms). Source: CIS } 2 \text {. }\end{array}$ & 0.259 & 0.162 \\
\hline $\begin{array}{l}\text { Innovation Expenditure } \\
\text { in Services }\end{array}$ & $\begin{array}{l}\text { Innovation Expenditure by service firms as } \\
\% \text { of turnover (all services firms). Source: } \\
\text { CIS } 2 \text {. }\end{array}$ & 0.131 & 0.188 \\
\hline Public R\&D & $\begin{array}{l}\text { Public R\&D spending as a \% of GDP. } \\
\text { Source Eurostat. }\end{array}$ & 0.263 & 0.190 \\
\hline National Public R\&D & $\begin{array}{l}\text { National public R\&D spending as a } \% \text { of } \\
\text { GDP. Source Eurostat. }\end{array}$ & 0.269 & 0.058 \\
\hline National Business R\&D & $\begin{array}{l}\text { National business R\&D spending as a } \% \text { of } \\
\text { GDP. Source: Eurostat. }\end{array}$ & 0.206 & 0.063 \\
\hline
\end{tabular}




\section{References}

Arundel. A., Smith. K., Patel. P. and Sirilli. G., (1998) The Future of Innovation Measurement in Europe - Concepts, Problems and Practical Directions, IDEA Paper Series, No.3., http://www.sol.no/step/IDEA/.

Audretsch D B and Feldman M P (1996) 'R\&D spillovers and the geography of innovation and production', American Economic Review, 86, 630-640.

Best, M. (2000) 'The Capabilities and Innovation Perspective: The Way Ahead in Northern Ireland' Research Monograph 8, December. Belfast: Northern Ireland Economic Council.

Beugelsdijck S and Cornet M (2001) 'How far do they reach? The localisation of industrial and academic spillovers in the Netherlands', Centre discussion paper 200147.

Boynton, A Zmud, R and Jacobs, G (1994) 'The Influence of IT management practice on IT use in large organisations', MIS Quarterly, 18, 299-320.

Braczyk, H-J, Cooke, P and Heidenreich, M (1998) 'Regional Innovation Systems', UCL Press, London.

Chandler, A D (1990) 'Scale and Scope: The Dynamics of Industrial Capitalism', Harvard University Press, Cambridge, MA.

Cockburn, L and Henderson, H (1998) 'Absorptive capacity, co-authoring behaviour and the organisation of research in the drug industry', Journal of Industrial Economics, 46, 157-183.

Cohen W M and Levinthal D A (1989) 'Innovation and learning: the two faces of R\&D', Economic Journal, 99, 569-596.

Cohen W M and Levinthal D A (1990) 'Absorptive capacity: a new perspective on learning and innovation', Administrative Science Quarterly, 35, 128-152.

Cooke, P N and Morgan, K (1998) 'The associational economy: Firms, regions, and innovation', Oxford University Press.

Dahlman, C and Nelson, R (1995) 'Social absorption capability, national innovation systems and economic development' in Perkins, D H and Koo, B H (eds.) 'Social Capability and Long Term Growth', MacMillan Press, Basingstoke.

Develaar E and Nijkamp, P (1989) 'Spatial Dispersion of Technological Innovation: A Case Study for the Netherlands By Means of Partial Least Squares', Journal of Regional Science, 29, 3, 325-346.

Develaar, E and Nijkamp, P (1992) 'Operational Models on Industrial Innovation and Spatial Development: A Case Study for the Netherlands', Journal of Scientific and Industrial Research, 51, 253-284. 
Dobkins, LH (1996) 'Location, innovation and trade: the role of localisation and nation-based externalities', Regional Science and Urban Economics, 26, 6, 591-612.

Dolton, P. \& Vignoles, A. (2000). The Incidence and effects of over-education in the U.K. graduate labour market. Economics of Education Review, 19, 179-198.

EU (1998) Regional Innovation systems: Designing for the Future - REGIS. Final report of the REGIS project, Targeted Socio-Economic Research (TSER) Programme (co-ordinator: Cooke, P ) European Commission DG XII.

European Commission (2003) European Innovation Scoreboard Technical Paper No 3 - Regional Innovation Performances.

Fernandez, E Junquera, B and Vazquez, C J (1996) 'Government Support for R\&D: The Spanish Case', Technovation, 16, 2, 59-66.

Finegold, D. and Wagner, K. 1998. The search for flexibility: skills and workplace innovation in the German pump industry', British Journal of Industrial Relations, vol. $36,469-487$

Freel, M S (2003) 'Patterns of innovation and skills in small firms', Technovation, forthcoming.

Grabher, G. and Stark, D. 1997. Organising diversity: evolutionary theory, network analysis and post-socialism", Regional Studies, vol. 31, 533-544

Griliches Z (1979) 'Issues in assessing the contribution of research and development to productivity growth', Bell Journal of Economics, 10, 92-116.

Griliches Z (1992) 'The search for R\&D spillovers', Scandinavian Journal of Economics, 94 (supplement), 29-47.

Guellec, D and van Pottelsberghe de la Potterie (2001) 'The Effectiveness of Public $R \& D$ Policies in OECD Countries', OECD, Paris.

Herrigel, G. 1996. Crisis in German decentralised production, European Urban and Regional Studies, vol. 3, 33-52

Hewitt-Dundas, N Anderson-Callaghan, B Crone, M Murray, J and Roper, S (2002) 'Learning from the Best - Knowledge Transfers from Multinational Plants in IrelandA North-South Comparison', NIERC/EAC, Belfast.

Jones O and Craven M (2001) 'Beyond the Routine: Innovation Management and the Teaching Company Scheme’, Technovation, 21, 5, 267-279.

Keller, W (1996) 'Absorptive capacity - On the creation and acquisition of technology in development, Journal of Developmental Economics, 49, 199-210. 
Kleinknecht, A and Poot, T P (1992) 'Do Regions Matter for R\&D?', Regional Studies, 32, 221-32.

Kogut, B. (1988). 'Joint ventures: theoretical and empirical perspectives', Strategic Management Journal, 9, 319-32.

Koschatzky, K Frenkel, A Walter, G H and Shefer, D (1998) 'Regional Concentration and Dynamics of Fast Growing Industries in Baden-Wurttemberg and Israel', ISIArbeitspapiere Regionalforschung, Nr 14.

Lane, C. 1997. The social regulation of inter-firm relations in Britain and Germany: market rules, legal norms and technical standards, Cambridge Journal of Economics, vol. 21, 197-215

Love, J H and Roper, S (2001) "Location and Network Effects on Innovation Success: Evidence for UK, German and Irish Manufacturing Plants", Research Policy, 30, 4, 643-661.

Love J H and Roper S (2004) 'The organisation of innovation: collaboration, cooperation and multifunctional groups in UK and German manufacturing', Cambridge Journal of Economics, 28,

Lundvall, B.A. and Johnson, B. (1994) 'The Learning Economy', Journal of Industry Studies, 1, 23-42.

Mamuneas, T P and Nadiri, M I (1996) 'Public R\&D Policies and Cost Behaviour of US Manufacturing Industries', Journal of Public Economics, 63, 57-81.

Metcalfe, S (1997) 'Technology Systems and Technology Policy in an Evolutionary Framework', in 'Technology, Globalisation and Economic Performance', Archibugi, $\mathrm{D}$ and Michie, J (eds), Cambridge University Press.

Michie, J and Sheehan, M (2003) 'Labour Market Deregulation, 'Flexibility' and Innovation', Cambridge Journal of Economics. Vol. 27 (1). p 123-43. January 2003.

Morgan, K. 1997. The learning region: institutions, innovation and regional renewal, Regional Studies, vol. 31, 491-503

Muller E, and Zenker A (2001) 'Business services as actors of knowledge transformation: the role of KIBS in regional and national innovation systems', Research Policy, 30, 9, 1501-1516.

Nasierowski, W and Arcelus, F J (1999) 'Inter-relationships Among the Elements of National Innovation Systems: A Statistical Evaluation', European Journal of Operations Research, 119, 2, 235-253.

Narula, R (2004) 'Understanding Absorptive capacities in an 'innovation systems context: consequences for economic and employment growth', MERIT - Infonomics research memorandum series 2004-003. 
Nelson, R.R. 1993. National Innovation Systems, New York, Oxford University Press

Oerlemans, L A G Meus, M T H and Boekema, F W M (1998) 'Do Networks Matter for Innovation? The Usefulness of the Economic Network Approach in Analysing Innovation', Tijdschrift voor Economische en Sociale Geografie, 89, 3, 298-309.

Psacharopoulos, G (1994) 'Returns to Investment in Education - A Global Update', World Development, 22, 9, 1325-1343.

Rodríguez-Pose, A. (2001) 'Is R\&D investment in lagging areas of Europe worthwhile? Theory and empirical evidence', Papers in Regional Science, 80, 3, 27595.

Roper, S (2001) 'Innovation, Networks and Plant Location; Evidence for Ireland', Regional Studies, 35, 3, 215-228.

Roper, S Hewitt-Dundas, N and J H Love (2003) 'R\&D Centres in Less Favoured Regions - Towards An Ex Ante Impact Assessment' in O'Leary, E (ed.) 'Ireland 2020', Liffey Press, Dublin.

Roper, S Hewitt-Dundas, N and Love, J H (2004) 'An Ex Ante Evaluation Framework for the Regional Benefits of Publicly Supported R\&D Projects', Research Policy, 33, 487-509.

Sandven. T., Pedersen. T.E. and Smith. K., (1998) Analysis of CIS Data on the Impact of Innovation on Growth in the Sector of Manufacturing of Machinery and Equipment and of Electrical Machinery, DG - Enterprise, Innovation \& SME Programme, CIS 98/188, ftp://ftp.cordis.lu/pub/eims/docs/eims_full text 98 188.pdf

Song, X. M., Montoya-Weiss, M. M. and Schmidt, J. B. 1997. Antecedents and consequences of cross functional co-operation: a comparison of $\mathrm{R} \& \mathrm{D}$, manufacturing and marketing perspectives, Journal of Product Innovation Management, vol. 14, 3547.

Szulanski, G (1996) 'Exploring Internal stickiness: Impediments to the transfer of best practice within the firm', Strategic Management Journal, 17, 27-43.

van den Bosch F A J, van Wijk R and Volberda H W (2003) 'Absorptive capacity: antecedents, models and outcomes', ERIM Report ERS-2003-035-STR, Erasmus Research Institute of Management, Rotterdam.

Veugelers, R (1997) 'Internal R\&D Expenditures and External Technology Sourcing', Research Policy, 26, 303-315.

Veugelers, R and Cassiman, B (1999) 'Make and buy in innovation strategies: evidence from Belgian manufacturing firms', Research Policy, vol. 28, 63-80.

Whittington, R Mayer, M and Curto, F (1999) 'Chandlerism in Post-War Europe: Strategic and Structural Change in France, Germany and the UK, 1950-1993', Industrial and Corporate Change, 8, 3, 519-551. 
Zahra S A and George G (2002) 'Absorptive capacity: a review, re-conceptualization, and extension', Academy of Management Review, 27, 185-203.

Zucker L G, Darby M R and Armstrong J (1998a) 'Geographically localised knowledge: spillovers or markets?, Economic Inquiry, 36, 65-86.

Zucker L G, Darby M R and Bewer M B (1998b) 'Intellectual human capital and the birth of US biotechnology enterprises', American Economic Review, 88, 290-306. 